\title{
Pastoralism and wild life: historical and current perspectives in the East African rangelands of Kenya and Tanzania
}

\author{
F. Lankester ${ }^{(1) *} \&$ A. Davis ${ }^{(2)}$ \\ (1) Paul G. Allen School for Global Animal Health, Washington State University, Pullman, Washington, United \\ States of America \\ (2) School of Geographical and Earth Sciences, University of Glasgow, Glasgow, United Kingdom \\ *Corresponding author: lankesterf@vetmed.wsu.edu
}

\begin{abstract}
Summary
The relationship between pastoralists, their livestock, wildlife and the rangelands of East Africa is multi-directional, complex and long-standing. The tumultuous events of the past century, however, have rewritten the nature of this relationship, reshaping the landscapes that were created, and relied upon, by both pastoralists and wildlife. Presently, much of the interaction between wildlife and pastoralists takes place in and around protected areas, the most contentious occurring in pastoral lands surrounding national parks. In conservation terminology these areas are called buffer zones. In the past century buffer zones have been shaped by, and contributed to, restrictive conservation policies, expropriation of land, efforts to include communities in conservation, both positive and negative wild life/livestock interactions, and political tensions. In this review paper, the authors outline the history that shaped the current relationship between pastoralists, livestock and wildlife in buffer zones in East Africa and highlight some of the broader issues that pastoralists (and pastoralism as an effective livelihood strategy) now face. Finally, they consider some of the sustainable and equitable practices that could be implemented to improve livelihoods and benefit wildlife and pastoralism alike.
\end{abstract}

\section{Keywords}

Buffer zone - Conservation - East Africa - Infectious disease - Pastoralism - Rangelands - Wildlife.

\section{Pastoralism in East Africa: a brief overview}

Pastoralism emerged in East Africa (Kenya, Tanzania and Uganda) around $4000 \mathrm{BP}(1,2)$ as a culturally and linguistically diverse range of societies with differences in terms of the livestock species kept (small ruminants, cattle, camels) and the degree to which hunting and small-scale, rain-fed agriculture were practised and relied upon $(3,4)$. Despite differences, pastoral societies likely faced similar challenges, with drought, disease, and insecurity being the most critical (5). To cope with such challenges, mobility across rangelands held as a common property resource (CPR) developed, enabling East African pastoralists over the centuries to successfully exploit semi-arid environments with heterogeneous and unpredictable rainfall and pasture quality $(2,6,7,8,9)$. Through grazing and the use of fire, pastoralists and their livestock played a role in shaping the ecology of rangeland landscapes, in particular, impacting the composition and nutrient content of grass species and the degree of tree cover $(10,11,12,13)$.

\section{Wildlife and rangelands}

Similar challenges affected the survival of wildlife in East African rangelands, with mobility again being a solution (12). Grazing herbivores such as wildebeest (Connochaetes spp.) and Thomson's gazelles (Eudorcas thomsonii) migrate to access seasonal rainfall-driven food supplies (14). Carnivore species, such as wild dogs (Lycaon pictus) and cheetah (Acinonyx jubatus) follow herbivores (15). And, like pastoralists, wildlife also play a role in shaping rangeland ecology, with large species such as elephants (Loxodonta africana) transforming the savannah by reducing the rate of woodland expansion, and the migration cycles of the herbivores providing annual periods (when the grazers 
move away) during which the grass is able to set seed and reproduce $(12,16)$. Indeed, without migration and the resultant grazing-free periods, the grasslands would have to sustain much lower densities of grazers if they were not to be destroyed (17).

\section{Pastoralism and wildlife}

Pastoralist/wildlife interactions go beyond co-creation of landscapes. Wild grazers use proximity to pastoralist homesteads to avoid non-human predators and exploit dams, built for livestock, as a source of water (18). Pastoralists create and set aside rich pasture for their livestock herds, providing nutritional benefits to wild herbivores. When transhumant pastoralists move, nutrientdense forage flourishes in the richly fertilised soil on which their homesteads stood (19). Further, it has been suggested that species such as gazelles and wildebeest, which prefer the short grass that emerges following grazing succession in which coarse grass is stripped to reveal nutrient-rich young shoots and cut basal stems $(20,21)$, actually benefit from the grazing of livestock $(12,18)$. Even the planted trees ('live fencing') around the livestock corral provide shade and cover for ungulates hiding from predators (12).

Benefits also flow the other way. Since pre-historic times pastoralists have, in times of drought, disease or other adverse conditions, hunted wildlife for food (12). Pastoralists have also utilised wild herbivores to track forage availability for their livestock and, through close observation of movement patterns, have relied on species such as wildebeest as indicators of rainfall (18).

The presence of wildlife on the rangelands has also presented many challenges to pastoralists. Species such as elephant and buffalo (Syncerus caffer) pose threats to human life and, together with smaller herbivores, cause crop damage, whilst carnivore species prey upon livestock. There has also been an ongoing debate about the importance of grazing competition between wild and domestic species (22). One of the most significant challenges posed by wildlife, however, involves the transmission of infectious disease (23). Indeed, archaeological evidence suggests the first 'pastoralist' colonisation of sub-Saharan Africa was a halting process, with cattle-based economies in eastern Africa not appearing until a thousand years after the introduction of small stock $(11,24)$, possibly due to exposure to endemic wildlife diseases (trypanosomiasis, wildebeest-associated malignant catarrhal fever [MCF], East Coast fever [ECF] and Rift Valley fever) that were novel and virulent in cattle (11). Consequently, early pastoralists may have only settled in the rangelands south of the Sahel after consolidating ethnoveterinary epizootiological knowledge and the evolution of disease avoidance strategies such as:
- burning practices that encouraged fire-tolerant grass species $(11,25)$ and also killed tick vectors for diseases such as ECF

- clearing woodlands for fuel, building materials and agricultural planting, which had the effect of reducing the habitat for tsetse vectors of trypanosomiasis $(11,26)$

- avoiding wildebeest calving areas to reduce transmission of MCF.

Avoidance of wooded areas (except in times of drought when the need for forage was greatest and the vector populations lowest) and crossing woodland belts at night (when tsetse were not active) also reduced disease threats. Disease exposure was not completely eliminated, however, and over time, the low-level exposure experienced by otherwise healthy animals is likely to have stimulated the development of immunity and evolution of endemic resistance in pastoralists' cattle (27). However, despite disease avoidance strategies and the development of resistance in cattle, disease continues to cause significant losses for pastoralists. A 23-year study estimated that disease caused twice the losses incurred by predation from carnivores (28), and recent work in Laikipia County (Kenya) puts the figure even higher (C. Amphlett, unpublished data, 2015). Nonetheless, despite an epidemiological role, only in relatively few (but important) diseases (e.g. MCF in wildebeest, bovine tuberculosis and foot and mouth disease in bovines, and anthrax in wild herbivores) are wildlife thought to contribute significantly to contemporary epidemics affecting livestock (29).

Thus, pastoralists and wildlife have co-existed and competed for millennia in the rangelands of East Africa using similar and complementary adaptations. However, at the end of the 19th Century, shifting socio-political factors began to dramatically reshape the East African landscape (30).

\section{The winds of change}

Several factors precipitated great change. In 1883, livestock in Kenya and Tanzania were hit by an outbreak of contagious bovine pleuropneumonia (31). In the 1890s, a rinderpest epidemic wiped out more than $95 \%$ of cattle in East Africa, whilst colonial and internecine warfare proliferated and novel diseases, such as smallpox and leishmaniasis, persisted (31). While the combined effects of these events on pastoralists varied, widespread famine significantly reduced pastoralist populations overall (31). For example, over two-thirds of the population of Maasai pastoralists in Kenya and Tanzania perished and the ecological systems they managed collapsed (31).

The decimation of the pastoralist populations led to a reduction in their vegetation-controlling practices 
(i.e. grazing, burning), which resulted in a massive expansion of acacia woodland and bushy thickets throughout East African rangelands. This, in turn, led to a proliferation of tsetse flies, increasing the incidence of trypanosomiasis. The threat of cattle contracting this lethal disease discouraged people from returning to their homesteads, forcing them away from their ancestral lands $(12,27,32)$.

The rinderpest epidemic also had a dramatic impact on rangeland ecological dynamics. Wild ungulate populations, e.g. Cape buffalo, eland (Taurotragus oryx), giraffe (Giraffa camelopardalis) and wildebeest, were highly susceptible and their populations were decimated, as were ungulatedependent predators. Not all wildlife species were equally affected, however: Thompson's gazelles (Eudorcas thomsonii), Grant's gazelles (Nanger granti), topi (Damaliscus korrigum) and others were only moderately affected, whilst populations of elephant, rhino (Rhinocerotidae), zebra (Equus quagga) and hippo (Hippopotamus amphibius) actually increased (12).

This new dynamic, a landscape sparsely populated by people and dominated by rinderpest-resistant wildlife populations, coincided with the post-Berlin Conference (1884-1885) arrival of colonial administrations which, assuming this dynamic to be the norm rather than a unique historical moment (10), set it as the benchmark against which wildlife conservation has been judged ever since. Further, in the early decades of the 1900s when the colonial domination of East Africa was at its peak, the large populations of many wildlife species and, more specifically, their availability to be hunted, were seen as an asset by the colonial administrators to attract the European gentry and their money to Africa. Trophy hunting became an important and protected source of revenue (30), and indigenous pastoralists and their livestock, rather than being viewed as integral to these landscapes, were often considered to be living incompatibly with wildlife conservation and something from which the rangelands, and wildlife in particular, needed protection (12).

This ideology led to the expropriation of large tracts of land to be set aside for exclusive wildlife-related activities such as hunting (predominantly by white elites), tourism and conservation $(12,33)$. With the exception of the Ngorongoro Conservation Area (established in Tanzania in 1959), where pastoralists, in exchange for vacating the Serengeti, were granted secure tenure to live alongside wildlife within a multiple land-use protected area, the creation of national parks caused a rift between, and sought to separate, wildlife conservation and pastoralism.

Potentiating this rift were rangeland and social sciences that, during colonialism, developed novel criticisms of pastoralism. Pastoralists of East Africa were considered to suffer from a 'cattle complex' (34), in which large herds of cattle were irrationally kept for reasons of wealth and culture in numbers that were assumed to exceed the 'ecological carrying capacity' of the land. Inspired in part by the Dust Bowl catastrophe in the United States, it was thought that the pastoral rangelands of East Africa were so-called equilibrium environments, driven by classic feedback mechanisms (35). The consensus was that livestock populations and co-existing wildlife were limited by available forage in a density-dependent manner. Thus, if pastoralist herds were allowed to increase above carrying capacity, density-related crashes would inevitably follow, causing degradation and desertification. Outside observers assumed CPR lands to be open access to all with no regulation of use and that pastoral people were, in accordance with the 'tragedy of the commons' theory (36), individually exploiting resources for personal short-term gain at the expense of long-term stability. The avoidance of large-scale extinctions in the area was assumed to be a result of moving to new areas after degrading previously occupied environments (see Ellis \& Swift [37] for a critique of these rangeland degradation theories).

The discourse of irrational pastoralism was useful to, and influenced, conventional development practices of the colonial era, which included interventions to 'modernise' rangeland management. The principal objective of these 'blueprint' development interventions, beyond imposing colonial or state knowledge as superior to local land-use practices (38) and wrestling control of coveted resources from pastoralists, was to limit the number of livestock per unit area (6). Development projects were designed to 'settle' pastoralists in confined spaces (colonial reserves, ranches, villages) where the provision of resources and technical interventions could be managed by the state, to raise 'productivity' and better regulate the interaction between livestock and plants. These interventions were, however, based on the false social and ecological assumptions that pastoralists were not engaged in market behaviour, nor were they interested in 'improved' beef cattle, and that rangelands were equilibrial systems that, with good management, would have the capacity to support stable, balanced populations of livestock and people $(6,37)$.

\section{A modern perspective on a changing landscape}

As rangeland science has developed, the perceived equilibrium dynamics of rangeland ecosystems, and the appropriateness of modern ranching practices, have been increasingly called into question. Empirical studies in northern Kenya and Australia concluded that in droughtstressed rangelands, where single- and multiple-year 
droughts occur every four to ten years, it was the variability of the rainfall, and not its mean, that dominated vegetation dynamics. In these chaotic and variable systems vegetation productivity is more related to rainfall patterns than grazing intensity $(39,40,41)$, and to optimise productivity requires, just as pastoralists had devised millennia before, a system of mobility that enables access to pasture and water across a wide area $(2,37)$.

\section{The changing face of pastoralism}

However, due in part to the impacts of changes in land tenure, conservation and land fragmentation, keeping livestock in the traditional pastoralist manner in East Africa has, in recent decades, become increasingly difficult. Modern economic demands require pastoralist households to have access to cash to pay for health care, education and food, increasing the need for livelihood diversification to generate income $(42,43,44)$. From wage labour in cities (45), to involvement in gemstone mining and selling of beadwork and livestock products $(46,47)$, these shifts can be seen as coping strategies to protect households from having to sell livestock (48). One livelihood change that is steadily increasing, particularly in critical buffer zone areas in Kenya and Tanzania, and that has the potential to devastate pastoralism and wildlife, is the conversion of lands for cultivation, particularly large-scale cultivation (49, 50 ), which is often funded by outside investors.

\section{The impact of cultivation in pastoral communities and wildlife buffer zones}

In the past 50 years, pastoralists in East Africa have become increasingly reliant on agricultural products as well as participation in farming. The proliferation of agriculture has been caused, in part, by a growing preference for agricultural foods as well as the decline of livestock numbers relative to humans (44), but also reflects state biases in agricultural development. A reduction in the livestock per capita ratio, declining milk yields in the dry season, and an overall increase in food insecurity following drought or outbreaks of livestock disease have also contributed to this change (44). Additionally, government policies in East Africa, which view transhumant pastoralism as incompatible with ecological health (51), modernity or wildlife conservation (52), have pressured pastoralists to reduce livestock numbers and take up farming (51). For example, Tanzania's 'Kilimo Kwanza' ('Farming First') policy encourages agricultural production over pastoralism, leading to land disputes and resettlement to facilitate large-scale agricultural production (53). Cultivation is also viewed by pastoralists as a good way to stake a prior claim against threats of land being expropriated for conservation $(54,55,56)$ or conversion to industrial agriculture (57).

Despite growing pressures to cultivate, in many areas of East Africa rangeland aridity and marginal soil fertility limit the potential for cultivated food production. Additionally, rangeland cultivation removes dry season pastureland, which is vital for wild and domestic herbivores. Furthermore, some predict that climate change will make East African rangelands warmer, increase rainfall unpredictability, reduce plant-available moisture, and increase the frequency of extreme climatic events (58). These changes may favour mobile livestock keeping in non-fragmented rangelands, rather than cultivation which requires heavy inputs and leads to more fragmentation $(59,60,61)$.

The conversion of rangelands to agricultural plots also reduces the options for preventing infectious diseases in livestock (12). For example, with mobility increasingly restricted, traditional strategies such as grazing cattle away from wildebeest during calving season to avoid MCF are difficult to practise (12). This has resulted in significant losses, for example in cattle herds living near Lake Naivasha, Kenya (N. Lyons, unpublished data, 2015). Additionally, as grazing options become increasingly limited, herds are forced to share pastures, which increases the risk of transmissible and vector-borne diseases $(12,62)$.

Wildlife populations, which need to range widely to find forage and water (often outside of protected areas), are also affected by cultivation because it limits their mobility. When rangeland ecosystems surrounding protected areas are dominated by conservation-compatible land uses such as herding and small-scale farming, mobility is not inhibited and the biodiversity of the whole landscape benefits $(12,63)$; however, where large-scale land conversion for cultivation (primarily a product of state-driven leasing or selling of land to outside investors) has taken place around protected areas, the impact on wildlife can be devastating (63). For example, in Kenya, privatisation and conversion of formerly communal rangeland around the Maasai Mara National Reserve to commercial monoculture entailed drastic landcover changes resulting in significant wildlife declines (49, $64,65,66)$. A similar pattern is occurring around Tanzania's Tarangire National Park, where permanent subsistence and large-scale farming is increasingly isolating the park and leading to declines of large mammal species $(67,68)$. Additional factors that impact wildlife movements and close migration corridors, whilst also limiting access to traditional pastoral rangelands, include urbanisation and land segmentation, for example in Kajiado and Kitengela (Kenya) (69). 


\section{Conservation and community lands}

In recent years, therefore, it has become apparent that conservation goals are not only dependent on statecontrolled protected areas but also the viability of the surrounding community lands $(70,71,72)$ and on local people's tolerance of wildlife on those lands. This has led to a myriad of stakeholder-based initiatives $(72,73)$ such as Integrated Conservation and Development Programs, Community-Based Natural Resource Management, Community-Based Conservation, payments for ecosystem services (PES), private conservation easements, and, in Tanzania, state-driven and state-controlled 'community conservation' land management policies. These approaches primarily aim to conserve land outside protected areas, whilst compensating local communities for associated costs $(71,73,74,75)$. However, following scrutiny and critique $(42,71,72,74,76)$, it has been suggested that many of these measures have actually resulted in communities deriving limited benefits and, at times, incurring increased costs.

What are the reasons for community conservation failures? A long history of exclusion, resulting in antagonistic and contentious relationships between the pastoralist and conservation sectors, has stifled cooperation $(71,74,76$, $77,78,79,80)$. Furthermore, the relative marginalisation of pastoralists within conservation initiatives, their exclusion from decision-making processes regarding their land, and increased restrictions on the use of natural resources have contributed to fraught relationships (81). As a result many 'community-based' conservation initiatives fail, the fragmentation of rangelands increases and socio-political conflicts over land, land use, and livelihoods, especially in the contentious and important buffer zone areas, persist ( 7 , $55,56,81)$.

\section{Socially just and environmentally sustainable progressive pastoral policies}

The preceding discussion outlines the complex and codependent relationship of wildlife and pastoralism, both of which face a precarious future. Thus, there is a need to develop new policies for rangeland management that support both wildlife populations and livestock herds. While many perceive the conservation of wildlife as having an intrinsic value for humanity, it is also undoubtedly important for economic development. In East Africa, wildlife tourism is estimated to contribute $7-18 \%$ of GDP $(82,83)$.
Similarly, pastoralism contributes significantly throughout East Africa to national GDPs, potentially equivalent to the contribution of agriculture (84). Further, if human rights, cultural identities and marginalised communities are to be upheld and supported, the protection of pastoralist livelihoods is critical $(56,84,85)$. Consequently, there are both economic and culturally compelling reasons to ensure that the management of pastoral lands, particularly those surrounding protected areas, remains socially equitable and environmentally sustainable. To achieve this, progressive pastoral policies that learn from the failures and successes of community-based initiatives, and which respect local knowledge, land use, and livestock management practices, need to be developed. Furthermore, these progressive policies should balance the objectives of national conservation agendas with the cultural autonomy and self-determined development requirements of pastoral communities.

If interventions are to succeed, so that buffer-zone areas pay both biodiversity and livelihood dividends, they need to be built upon an understanding of the dynamics of the target systems on which they will be imposed. Rather than instituting wholesale changes it would be beneficial if the best aspects of the indigenous pastoral system were retained with flexibility built in, so that in times of drought demand on livestock can be reduced and wider access to food and markets made available $(37,86)$. The acknowledgement and facilitation of the strong links between pastoral communities and national economies will help in this respect $(37,84)$.

To ensure community support, initiatives that local people find useful should also be developed and the outputs, outcomes and impacts must be agreed upon at the outset by a diverse range of partners, including communities living in the target areas, researchers, and governmental and nongovernmental service providers $(86,87)$. For example, this approach, termed transdisciplinary research, has been used to help provide integrated health services in Chad $(88,89)$. Yet positive outcomes do not come from passive, consultative types of participation $(90,91)$. Local communities need to play active roles and have autonomy in decision-making, so that the decisions they take to act in different ways are recognised by powers beyond the local to have meaning and efficacy. To create the environment in which this can happen an element of social learning (for all stakeholders) should be implemented, in which the complex ecological issues at stake as well as local viewpoints, needs, and histories are considered. Importantly, it must not be just the views of the scientific elite that are incorporated into rangeland development programmes. Rather, investment in the social capital of pastoralist communities will be vital, especially in terms of providing access to critical resources within a community (50). For example, pastoral social organisations and networks should be provided space to lead so that development programmes are informed by 
indigenous knowledge. This may be time consuming and expensive but, if it ensures the full support of the community and stewardship over the long term, while building trust between partners (M. Goldman \& A. Davis, unpublished data), it may also pay dividends (90).

Any progressive pastoral policy, in addition to recognising and supporting mobility as a key strategy, must describe how the improvement of the efficiency of livestock production systems is to be achieved. For example, improvements can be made through the provision of improved veterinary care to control infectious diseases that impose significant costs on pastoralist livestock owners who are increasingly unable to exploit traditional avoidance strategies $(28,92)$. If successful, improvements in the efficiency of livestock systems could result in considerable economic benefits for the pastoral sector, as they will enable pastoralists to produce more livestock products to sell at local markets. One initiative that has successfully improved efficiency is the implementation of the 'infect and treat method' to protect cattle from East Coast fever. This strategy, which has been shown to be popular with pastoralists, results in fewer calf deaths, increased milk production and significant economic benefits to pastoral communities (93).

Ultimately, if East African pastoralism and wildlife are to thrive then pastoralists themselves will need to be given responsibility for looking after their land and provided with the political means to do so in a manner that is compatible with both livestock keeping and conservation (94). To facilitate this, pastoralism and the economic benefits it accrues, should be officially recognised at national levels as a viable livelihood strategy compatible with wildlife conservation. One way of doing this is to grant land tenure rights that guarantee the freedom to pursue a conservationcompatible mobile transhumant existence protected by law. Furthermore, pastoralists should play leading roles in the development of policies at national level and, perhaps more importantly, at regional level, as these policies will inevitably affect them most.

Pastoralist representation exists in places such as Ethiopia, Kenya, and Uganda, where various parliamentary bodies for pastoralists have been established with varying levels of formalisation (95). However, there is no universal agreement on what 'representation' may mean (96). While there are Members of Parliaments who represent pastoralist regions, formal pastoralist policies at national levels more often promote pastoralist 'modernisation' rather than support traditional pastoral livelihoods $(97,98,99)$. Consequently, in places such as Kenya and Tanzania, traditional pastoral interests are represented by active civil societies who are making strides to improve land use, secure tenure, build political forums and educate and empower local communities (100).

Pastoralism and wildlife have co-existed on the savannahs of East Africa for millennia. Since the 1800s the role this co-existence has played in 'managing' rangelands has been ignored and, in many places, replaced by Western management techniques and a belief that wildlife is best conserved in landscapes without people (12). As the dependence of rangeland protected areas on the ecological viability of the surrounding community lands (buffer zones) becomes apparent, so the efficacy of this isolationist strategy is increasingly called into question and the key role that the indigenous systems play in managing these semiarid lands becomes clear. With global human population growth, expansion of global capitalist markets and increased rangeland fragmentation making traditional pastoral systems increasingly difficult to maintain, progressive policies are required if the CPR lands surrounding protected areas, so vital to both conservation and pastoral communities alike, are to be managed in a sustainable manner. As has been the case for thousands of years, pastoralism and wildlife in East Africa remain entwined, with the futures of both in the balance. A forward-thinking holistic approach is required if this co-existence is to continue.

\section{Acknowledgements}

The authors thank Katherine Homewood and Mara Goldman for providing invaluable feedback and critical appraisal. 


\title{
Pastoralisme et faune sauvage : éclairage historique des parcours d'Afrique de l'Est et perspectives actuelles au Kenya et en Tanzanie
}

\author{
F. Lankester \& A. Davis
}

\begin{abstract}
Résumé
Les relations entre les pasteurs, leur bétail, la faune sauvage et les prairies d'Afrique de l'Est sont pluridimensionnelles, complexes et anciennes. Néanmoins, les bouleversements survenus au cours du $20^{\circ}$ siècle ont redéfini ces relations et redessiné des paysages qui avaient été durablement façonnés à la fois par les pasteurs et par la faune sauvage. Actuellement, la plupart des interactions entre la faune sauvage et les pasteurs ont lieu à l'intérieur et à proximité de zones protégées, les plus conflictuelles de ces interactions survenant dans les prairies qui entourent les parcs nationaux. Dans la terminologie de la protection de la nature, ces zones sont qualifiées de "zones tampons". Au siècle dernier, les zones tampons ont été tracées sous l'effet de facteurs qu'elles ont à leur tour contribué à renforcer : mesures restrictives de conservation, expropriation des terres, tentatives de réformes visant à intégrer les communautés locales dans les processus de conservation, interactions positives et négatives entre les animaux sauvages et le bétail, tensions politiques. Les auteurs apportent un éclairage historique afin d'expliquer les relations entre les pasteurs, le bétail et les animaux sauvages dans les zones tampons d'Afrique de l'Est et mettent en avant les problématiques plus larges auxquelles les pasteurs (et le pastoralisme en tant que stratégie de survie économique) sont actuellement confrontés. Enfin, ils proposent quelques solutions pour l'avenir, en lien avec des pratiques durables et équitables permettant d'améliorer les revenus des pasteurs afin de protéger la faune sauvage et de pérenniser le pastoralisme.
\end{abstract}

Mots-clés

Afrique de l'Est - Conservation - Faune sauvage - Maladie infectieuse - Pastoralisme Prairies - Zone tampon.

(1)

\section{Pastoreo y fauna salvaje: aspectos históricos y perspectivas actuales en los pastizales esteafricanos de Kenia y Tanzania}

\author{
F. Lankester \& A. Davis
}

\section{Resumen}

Las comunidades pastorales, su ganado, la fauna salvaje y los pastizales de África oriental mantienen entre sí una arraigada relación, compleja y poliédrica. Los tumultuosos acontecimientos del siglo pasado, sin embargo, redefinieron la naturaleza de esta relación y remodelaron los paisajes que los pastores y la fauna salvaje habían ido configurando y de los cuales dependían. A día de hoy el grueso de las interacciones entre la fauna salvaje y los pastores se produce en el interior o las inmediaciones de zonas protegidas: la cuestión resulta especialmente espinosa en las tierras de pastoreo que circundan los parques nacionales. En el léxico de la protección de la naturaleza estos espacios se denominan "zonas tampón". En el curso del pasado siglo se fueron delimitando zonas tampón que eran a la vez resultantes y generatrices de políticas restrictivas de protección, expropiaciones de tierras, iniciativas de reforma para incluir a las comunidades 
en las tareas de protección, interacciones (positivas o negativas) entre el ganado y la fauna salvaje y tensiones políticas. Tras repasar el devenir histórico que forjó la actual relación entre pastores, ganado y fauna salvaje en las zonas tampón de África oriental, los autores se detienen en algunos de los problemas de mayor calado a los que se enfrentan ahora las sociedades pastorales (y el pastoreo como medio de vida eficaz). Por último, también examinan posibles fórmulas para alumbrar usos sostenibles y equitativos que mejoren los medios de sustento y beneficien a la vez a la fauna salvaje y el pastoreo.

\section{Palabras clave}

África oriental - Enfermedad infecciosa - Fauna salvaje - Pastizales - Pastoreo Protección de la naturaleza - Zona tampón.

\section{References}

1. Marshall F. (2000). - The origins and spread of domestic animals in East Africa. In The origins and development of African livestock: archaeology, genetics, linguistics and ethnography (R. Blench \& K. MacDonald, eds). University College London Press, London.

2. Homewood K.M. (2008). - Ecology of African pastoralist societies. James Currey, Oxford.

3. Galaty J. (1993). - Maasai expansion and the new East African pastoralism. In Being Maasai: ethnicity and identity in East Africa (T. Spear \& R. Waller, eds). James Currey, London, $61-86$.

4. Spear T. \& Waller R. (1993). - Being Maasai: ethnicity and identity in East Africa. James Currey, London.

5. Little P.D. (2003). - Somalia: economy without state. Indiana University Press, Bloomington.

6. Scoones I. (1995). - New directions in pastoral development in Africa. In Living with uncertainty: new directions in pastoral development in Africa (I. Scoones, ed.). Intermediate Technology Publications, London, 1-36. doi:10.3362/9781780445335.001.

7. Galvin K.A., Reid R.S., Behnke R.H. \& Hobbs N.T. (2006). Fragmentation in semi-arid and arid landscapes: consequences for human and natural systems. Springer, New York.

8. Boone R.B., Burnsilver S.B., Worden J.S., Galvin K.A. \& Hobbs N.T. (2008). - Large-scale movements of large herbivores: livestock following changes in seasonal forage supply. In Resource ecology: spatial and temporal dynamics of foraging (H.H.T. Prins \& F. van Langevelde, eds). Springer, Dordrecht, 187-206. doi:10.1007/978-1-4020-6850-8_16.
9. McCabe J.T. (2004). - Cattle bring us to our enemies: Turkana ecology, politics, and raiding in a disequilibrium system. University of Michigan Press, Ann Arbor, Michigan.

10. Lamprey R. \& Waller R. (1990). - The Loita-Mara region in historical times: patterns of subsistence, settlement and ecological change. In Early pastoralists of south-western Kenya (P.T. Robertshaw, ed). British Institute in Eastern Africa, Nairobi, 16-35.

11. Gifford-Gonzalez D. (2000). - Animal disease challenges to the emergence of pastoralism in sub-Saharan Africa. African Archaeol. Rev., 17(3), 95-139. doi:10.1023/A:1006601020217.

12. Reid R.S. (2012). - Savannahs of our birth. University of California Press, Los Angeles.

13. Little P.D. (1996). - Pastoralism, biodiversity, and the shaping of savanna landscapes in East Africa. Africa: J. Int. African Inst., 66 (1), 37. doi:10.2307/1161510.

14. Maddock L. (1979). - The 'migration' and grazing succession. In Serengeti: Dynamics of an ecosystem (A.R.E. Sinclair \& M. Norton-Griffiths, eds). University of Chicago Press, Chicago, 104-129.

15. Bertram B.C.R. (1979). - Serengeti predators and their social systems. In Serengeti: Dynamics of an ecosystem (A.R.E. Sinclair \& M. Norton-Griffiths, eds). University of Chicago Press, Chicago, 221-248.

16. Sinclair A.R.E. (1995). - Equilibria in plant-herbivore interaction. In Serengeti II: Dynamics, management and conservation of an ecosystem (A.R.E. Sinclair \& P. Arcese, eds). University of Chicago Press, Chicago, 91-114. 
17. Sinclair A.R.E. \& Fryxell J.M. (1985). - The Sahel of Africa: ecology of a disaster. Can. J. Zool., 63 (5), 987-994. doi:10.1139/z85-147.

18. Goldman M. (2007). - Tracking wildebeest, locating knowledge: Maasai and conservation biology understandings of wildebeest behavior in northern Tanzania. Environ. Plan. D, Soc. Sp., 25 (2), 307-331. doi:10.1068/d0505.

19. Fynn R.W.S., Augustine D.J., Peel M.J.S. \& de Garine-Wichatitsky M. (2016). - Strategic management of livestock to improve biodiversity conservation in African savannahs: a conceptual basis for wildlife-livestock coexistence. J. Appl. Ecol., 53 (2), 388-397. doi:10.1111/13652664.12591.

20. Bell R.H.V. (1971). - A grazing ecosystem in the Serengeti. Sci. Am., 225 (1), 86-93. doi:10.1038/scientificamerican077186.

21. McNaughton S.J. (1985). - Ecology of a grazing ecosystem: the Serengeti. Ecol. Monogr., 55 (3), 260-294. doi:10.2307/1942578

22. Butt B. \& Turner M.D. (2012). - Clarifying competition: the case of wildlife and pastoral livestock in East Africa. Pastoralism: Res., Pol., Pract., 2 (1), 9. doi:10.1186/2041-7136-2-9.

23. Lembo T., Auty H., Hampson K., Craft M., Dobson A., Fyumagwa R., Eblate E., Haydon D., Hoare R., Kaare M., Lankester F., Mlengeya T., Travis D. \& Cleaveland S. (2015). - Infectious diseases in the Serengeti: what we know and how we know it. In Serengeti IV: Sustaining biodiversity in a coupled human-natural system (A.R.E. Sinclair, A. Dobson, K. Metzger \& J.M. Fryxell, eds). University of Chicago Press, Chicago.

24. Barthelme J.W. (1985). - Fisher-hunters and Neolithic pastoralists in East Turkana, Kenya. British Archaeological Reports, Oxford.

25. Pratt D.J. \& Gwynne M.D. (1977). - Rangeland management and ecology in East Africa. Hodder \& Stoughton, London.

26. Kjekshus H. (1977). - Ecology control and economic development in East African history. University of California Press, Berkeley.

27. Ford J. (1971). - The role of the trypanosomiases in African ecology. A study of the tsetse fly problem. Clarendon Press, Oxford.

28. Mizutani F., Muthiani E., Kristjanson P. \& Recke H. (2005). Impact and value of wildlife in pastoral livestock production systems in Kenya: possibilities for healthy ecosystem conservation and livestock development for the poor. In Occasional paper of the IUCN Species Survival Commission, No. 30. Conservation and development interventions at the wildlife/livestock interface: implications for wildlife, livestock and human health (S.A. Osofsky, S. Cleaveland, W. Karesh, M.D. Kock, P.J. Nyhus, L. Starr \& A. Yang, eds). International Union for Conservation of Nature, Gland, Switzerland, $121-132$
29. Plowright W. (1968), - Malignant catarrhal fever. J. Am. Vet. Med. Assoc., 152 (6), 795-805.

30. Enghoff M. (1990). - Wildlife conservation, ecological strategies and pastoral communities. A contribution to the understanding of parks and people in East Africa. Nomad. Peoples, 25-27, 93-107.

31. Waller R. (1988). - Emutai: crisis and response in Maasailand 1882-1902. In The ecology of survival: case studies from Northeast African history. Lester Crook Academic Publishing, London, 73-112.

32. Sinclair A.R.E. (1979). - The Serengeti environment. In Serengeti: Dynamics of an ecosystem (A.R.E. Sinclair \& M. Norton-Griffiths, eds). University of Chicago Press, Chicago, 31-45.

33. MacKenzie J.M. (1987). - Chivalry, social Darwinism and ritualised killing: the hunting ethos in Central Africa up to 1914. In Conservation in Africa: people, policies and practice (D. Anderson \& R. Grove, eds). Cambridge University Press, Cambridge.

34. Herskovits M.J. (1926). - The cattle complex in East Africa. Am. Anthropol., 28 (1), 230-272. doi:10.1525/ aa.1926.28.2.02a00030.

35. Anderson D. (1984). - Depression, dust bowl, demography and drought: the colonial state and soil conservation in East Africa during the 1930s. Afr. Affairs, 83 (332), 321-343.

36. Hardin G. (1968). - Tragedy of the commons. Science, 162 (3859), 1243-1248. doi:10.1126/science.162.3859.1243.

37. Ellis J.E. \& Swift D.M. (1988). - Stability of African pastoral ecosystems: alternate paradigms and implications for development. J. Range Manag., 41 (6), 450-459. doi: $10.2307 / 3899515$

38. Neumann R. (1995). - Ways of seeing Africa: colonial recasting of African society and landscape in Serengeti National Park. Ecumene, 2 (2), 149-169. doi:10.1177/147447409500200203.

39. Ellis J. (1995). - Climate variability and complex ecosystem dynamics: implications for pastoral development. In Living with uncertainty. New directions in pastoral development in Africa (I. Scoones, ed.). Intermediate Technology Publications, London, 37-46. doi:10.3362/9781780445335.002.

40. Noy-Meir I. (1982). - Stabilisation of plant-herbivore models and possible applications to savannas. Ecol. Stud., 42, 591609 .

41. Caughley G., Shepherd N. \& Short J. (1987). - Kangaroos: their ecology and management on the sheep rangelands of Australia. Cambridge University Press, Cambridge. doi:10.1017/cbo9780511898082. 
42. Homewood K., Chenevix Trench P. \& Kristjanson P. (2009). - Staying Maasai? Pastoral livelihoods, diversification and the role of wildlife in development. In Staying Maasai? Livelihoods, conservation and development in East African rangelands (K. Homewood, P. Kristjanson \& P. Chenevix Trench, eds). Springer Science \& Business Media, New York, 369-408. doi:10.1007/978-0-387-87492-0.

43. Homewood K.M., Trench P. \& Brockington D. (2012). Pastoralist livelihoods and wildlife revenues in East Africa: a case for coexistence? Pastoralism: Res., Pol., Pract., 2 (1), 19. doi:10.1186/2041-7136-2-19.

44. McCabe J.T., Leslie P.W. \& DeLuca L. (2010). - Adopting cultivation to remain pastoralists: the diversification of Maasai livelihoods in northern Tanzania. Hum. Ecol., 38 (3), 321-334. doi:10.1007/s10745-010-9312-8.

45. May A. \& McCabe J.T. (2004). - City work in a time of AIDS: Maasai labor migration in Tanzania. Afr. Today, 51 (2), 2-32. doi:10.2979/AFT.2004.51.2.2.

46. Sachedina H. \& Chenevix Trench P. (2009). - Cattle and crops, tourism and Tanzanite: poverty, land-use change and conservation in Simanjiro District, Tanzania. In Staying Maasai? Livelihoods, conservation and development in East African rangelands (K. Homewood, P. Kristjanson \& P. Chenevix Trench, eds). Springer Science \& Business Media, New York, 263-298. doi:10.1007/978-0-38787492-0_7.

47. Smith N.M. (2014). - Gender and livelihood diversification: Maasai women's market activities in northern Tanzania. J. Dev. Stud., 51 (3), 1-14. doi:10.1080/00220388.2014.957278.

48. O'Malley E.B. (2003). - Cattle and cultivation: changing land use and labor patterns in pastoral Maasai livelihoods, Loliondo Division, Ngorongoro District, Tanzania. University Microfilms International, Ann Arbor, Michigan.

49. Homewood K., Lambin E.F., Coast E., Kariuki A., Kikula I., Kivelia J., Said M., Serneels S. \& Thompson M. (2001). - Long-term changes in Serengeti-Mara wildebeest and land cover: pastoralism, population, or policies? Proc. Natl Acad. Sci. USA, 98 (22), 12544-12549. doi:10.1073/ pnas.221053998.

50. Galvin K.A. (2009). - Transitions: pastoralists living with change. Annu. Rev. Anthropol., 38 (1), 185-198. doi:10.1146/ annurev-anthro-091908-164442.

51. Looloitai L. (2014). - Land policy and the Maasai in Tanzania: the demise of pastoralism? MA Thesis. Erasmus University, Institute of Social Studies, the Hague. Available at: http://hdl. handle.net/2105/17338.

52. Benjaminsen T.A., Maganga F.P. \& Abdallah J.M. (2009). - The Kilosa killings: political ecology of a farmer-herder conflict in Tanzania. Dev. Change, 40 (3), 423-445. doi:10.1111/j.14677660.2009.01558.x.
53. Mahonge C.P.I., Sangeda A.Z. \& Mtengeti E.J. (2014). Mismatch between state's and community's boundaries and implications on pastoralism in Tanzania. Int. J. Res. Soc. Sci., 4 (1), 132-142.

54. Fairhead J., Leach M. \& Scoones I. (2012). - Green grabbing: a new appropriation of nature? J. Peasant Stud., 39 (2), 37-41. doi:10.1080/03066150.2012.671770.

55. Gardner B. (2012). - Tourism and the politics of the global land grab in Tanzania: markets, appropriation and recognition. J. Peasant Stud., 39 (2), 377-402. doi:10.1080/03066150.201 2.666973.

56. Benjaminsen T.A. \& Bryceson I. (2012). - Conservation, green/blue grabbing and accumulation by dispossession in Tanzania. J. Peasant Stud., 39 (2), 335-355. doi:10.1080/0306 6150.2012 .667405

57. Homewood K., Kristjanson P. \& Chenevix Trench P. (2009). - Changing land use, livelihoods and wildlife in Maasailand. In Staying Maasai? Livelihoods, conservation and development in East African rangelands (K. Homewood, P. Kristjanson $\&$ P. Chenevix Trench, eds). Springer Science \& Business Media, New York, 1-42. doi:10.1007/978-0-387-87492-0_1.

58. Stige L.C., Stave J., Chan K.S., Ciannelli L., Pettorelli N., Glantz M., Herren H.R. \& Stenseth N.C. (2006). - The effect of climate variation on agro-pastoral production in Africa. Proc. Natl Acad. Sci. USA, 103 (9), 3049-3053. doi:10.1073/ pnas.0600057103.

59. Galvin K.A. (2008). - Responses of pastoralists to land fragmentation: social capital, connectivity and resilience. In Fragmentation in semi-arid and arid landscapes: consequences for human and natural systems (K.A. Galvin, R.S. Reid, R.H. Behnke \& N. Thompson Hobbs, eds). Springer, Dordrecht, the Netherlands, 369-390. doi:10.1007/978-14020-4906-4_15.

60. Hobbs N.T., Galvin K.A., Stokes C.J., Lackett J.M., Ash A.J., Boone R.B., Reid R.S. \& Thornton P.K. (2008). Fragmentation of rangelands: implications for humans, animals, and landscapes. Glob. Environ. Chang., 18 (4), 776785. doi:10.1016/j.gloenvcha.2008.07.011.

61. Davies J. \& Nori M. (2008). - Managing and mitigating climate change through pastoralism. In Policy matters: newsletter of the IUCN Commission on Environmental, Economic and Social Policy, No. 16. International Union for Conservation of Nature, Gland, Switzerland, 127-141.

62. Cleaveland S., Kusiluka L., Ole Kuwai J., Bell C. \& Kazwala R. (2001). - Assessing the impact of malignant catarrhal fever in Ngorongoro District, Tanzania. A study commissioned by the Animal Health Programme of the United Kingdom Department for International Development. Available at: www.eldis.org/go/ home\&id=11676\&type=Document\#.V6S4jtocTcs.

63. Homewood K.M. (2004). - Policy, environment and development in African rangelands. Environ. Sci. Pol., 7 (3), 125-143. doi:10.1016/j.envsci.2003.12.006. 
64. Norton-Griffiths M. (1996). - Property rights and the marginal wildebeest: an economic analysis of wildlife conservation options in Kenya. Biodivers. Conserv., 5 (2), 1557-1577. doi:10.1007/BF00052116.

65. Thompson M. \& Homewood K. (2002). - Entrepreneurs, elites, and exclusion in Maasailand: trends in wildlife conservation and pastoralist development. Hum. Ecol., 30 (1), 107-138. doi:10.1023/A:1014519113923.

66. Lamprey R.H. \& Reid R.S. (2004). - Expansion of human settlement in Kenya's Maasai Mara: What future for pastoralism and wildlife? J. Biogeogr., 31 (6), 997-1032. doi:10.1111/ j.1365-2699.2004.01062.x.

67. Borner M. (1985). - The increasing isolation of Tarangire National Park. Oryx, 19 (02), 91-96. doi:10.1017/ S0030605300019797.

68. Tarangire Conservation Project (1998). - Analysis of migratory movements of large mammals and their interactions with human activities in the Tarangire area in Tanzania as a contribution to a conservation and sustainable development strategy. Final Report.

69. Reid R.S., Gichohi H., Said M.Y., Nkedianye D., Ogutu J.O., Kshatriya M., Kristjanson P., Kifugo S.C., Agatsiva J.L., Adanje S.A. \& Bagine R. (2008). - Fragmentation of a peri-urban savanna, Athi-Kaputieli Plains, Kenya. In Fragmentation in semi-arid and arid landscapes: consequences for human and natural systems (K.A. Galvin, R.S. Reid, R.H. Behnke \& N.T. Hobbs, eds). Springer, Dordrecht, the Netherlands, 195-224. doi:10.1007/978-14020-4906-4_9.

70. Sachedina H.T. (2010). - Disconnected nature: the scaling up of African Wildlife Foundation and its impacts on biodiversity conservation and local livelihoods. Antipode, 42 (3), 603-623. doi:10.1111/j.1467-8330.2010.00765.x.

71. Goldman M. (2003). - Partitioned nature, privileged knowledge: community-based conservation in Tanzania. Dev. Change, 34 (5), 833-862. doi:10.1111/j.14677660.2003.00331.x.

72. Hulme D. \& Murphree M. (eds) (2001). - African wildlife and livelihoods: the promise and performance of community conservation. James Currey, Oxford.

73. Galvin K.A., Thornton P.K., de Pinho J.R., Sunderland J. $\&$ Boone R.B. (2006). - Integrated modeling and its potential for resolving conflicts between conservation and people in the rangelands of East Africa. Hum. Ecol., 34 (2), 155-183. doi:10.1007/s10745-006-9012-6

74. Igoe J. (2004). - Conservation and globalization: a study of national parks and indigenous communities from East Africa to South Dakota. Wadsworth Thompson Learning, Belmont, USA.

75. Sulle E., Lekaita E. \& Nelson F. (2011). - From promise to performance: wildlife management areas in northern Tanzania. Available at: www.tnrf.org/files/WMA_summary.pdf.
76. Davis A. (2011). - 'Ha! What is the benefit of living next to the park?' Factors limiting in-migration next to Tarangire National Park, Tanzania. Conserv. Soc., 9 (1), 25-34. doi:10.4103/0972-4923.79184.

77. Kabiri N. (2010). - The political economy of wildlife conservation and decline in Kenya. J. Environ. Dev., 19 (4), 424-445. doi:10.1177/1070496510384463.

78. Goldman M.J., de Pinho J.R. \& Perry J. (2013). - Beyond ritual and economics: Maasai lion hunting and conservation politics. Oryx, 47 (4), 490-500. doi:10.1017/ S0030605312000907

79. Brockington D. (2002). - Fortress conservation: the preservation of the Mkomazi Game Reserve, Tanzania. Indiana University Press, Bloomington.

80. Hughes L. (2008). - Rough time in paradise: claims, blames and memory making around some protected areas in Kenya. Conserv. Soc., 5 (3), 307-330.

81. Goldman M. (2011). - Strangers in their own land: Maasai and wildlife conservation in northern Tanzania. Conserv. Soc., 9 (1), 65-79. doi:10.4103/0972-4923.79194.

82. Development Partners Group (Tanzania) (2015). - The wildlife sector with emphasis on tourist hunting. Available at: www.tzdpg.or.tz/dpg-website/dpg-tanzania.html.

83. Korir J., Muchiri J. \& Kamwea J. (2013). - Wildlife-based tourism, ecology and sustainability of protected areas in Kenya. J. Nat. Sci. Res., 3 (3), 40-48.

84. Behnke R. \& Muthami D. (2011). - The contribution of livestock to the Kenyan economy. IGAD LPI Working Paper 03-11. Intergovernmental Authority on Development (IGAD) Livestock Policy Initiative (LPI), Addis Ababa, Ethiopia.

85. Brockington D., Igoe J. \& Schmidt-Soltau K.A. (2006). - Conservation, human rights, and poverty reduction. Conserv. Biol., 20 (1), 250-252. doi:10.1111/j.15231739.2006.00335.x.

86. Kristjanson P., Reid R.S., Dickson N., Clark W.C., Romney D., Puskur R., Macmillan S. \& Grace D. (2009). Linking international agricultural research knowledge with action for sustainable development. Proc. Natl Acad. Sci. USA, 106 (13), 5047-5052. doi:10.1073/pnas.0807414106.

87. Reid R.S., Nkedianye D., Said M.Y., Kaelo D., Neselle M., Makui O., Onetu L., Kiruswa S., Kamuaro N.O., Kristjanson P., Ogutu J., BurnSilver S.B., Goldman M.J., Boone R.B., Galvin K.A., Dickson N.M. \& Clark W.C. (2016). - Evolution of models to support community and policy action with science: balancing pastoral livelihoods and wildlife conservation in savannas of East Africa. Sackler Special Feature on Sustainable Development. Paper resulting from the Arthur M. Sackler Colloquium of the National Academy of Sciences, 'Linking knowledge with action for sustainable development', 3-4 April, 2009, Washington, DC. Proc. Natl Acad. Sci. USA, 113 (17), 4579-4584. doi:10.1073/pnas.0900313106. 
88. Hirsch Hadorn G., Hoffmann-Reim H., Biber-Klemm S., Grossenbacher-Mansuy W., Joye D., Pohl C., Wiesmann U. \& Zemp E. (2008). - Handbook of transdisciplinary research. Springer, Dordrecht. doi:10.1007/978-1-4020-6699-3.

89. Schelling E., Wyss K., Diguimbaye C., Béchir M., Taleb M.O., Bonfoh B., Tanner M. \& Zinsstag J. (2008). Towards integrated and adapted health services for nomadic pastoralists and their animals: a North-South partnership. In Handbook of transdisciplinary research (G. Hirsch Hadon, H. Hoffmann-Riem, S. Biber-Klemm, W. GrossenbacherMansuy, D. Joye, C. Pohl, U. Wiesmann \& E. Zemp eds). Springer, Dordrecht, 277-291. doi:10.1007/978-1-40206699-3_17.

90. Pretty J. \& Smith D. (2004). - Social capital in biodiversity conservation and management. Conserv. Biol., 18 (3), 631638. doi:10.1111/j.1523-1739.2004.00126.x.

91. Goldman M.J. (2014). - From critique to engagement : reevaluating the participatory model with Maasai in northern Tanzania. J. Polit. Ecol., 21, 408-423.

92. Homewood K. \& Rogers W.A. (1991). - Maasailand ecology: pastoralist development and wildlife conservation in Ngorongoro Conservation Area, Tanzania. Cambridge University Press, Cambridge. doi:10.1017/ CBO9780511525568.

93. Marsh T.L. \& Yoder J. (2013). - Economic assessment of ECF vaccination on Kenyan pastoral households. GALVmed, Edinburgh \& Washington State University, Pullman, Washington.

94. Kock R.A. (2005). - What is this infamous 'wildlife/livestock disease interface?' A review of current knowledge for the African continent. In Occasional paper of the IUCN Species Survival Commission, No. 30. Conservation and development interventions at the wildlife/livestock interface: implications for wildlife, livestock and human health (S.A. Osofsky, S. Cleaveland, W. Karesh, M.D. Kock, P.J. Nyhus, L. Starr \& A. Yang, eds). International Union for Conservation of Nature, Gland, Switzerland.
95. Morton J. (2005). - Legislators and livestock: a comparative analysis of pastoralist parliamentary groups in Ethiopia, Kenya and Uganda, 1-27. Available at: www.nri.org/ projects/pastoralism/synthesisreportaprilfinal.pdf.

96. Lister S. (2004). - The processes and dynamics of pastoralist representation in Ethiopia. IDS Working Paper No. 38. Institute for Development Studies (IDS), Brighton.

97. Fratkin E. (2001). - East African pastoralism in transition: Maasai, Boran, and Rendille cases. Afr. Stud. Rev., 44 (3), 1-25. doi:10.2307/525591.

98. Hesse C. \& MacGregor J. (2006). - Pastoralism: drylands' invisible asset? Developing a framework for assessing the value of pastoralism in East Africa. IIED Issue Paper No. 142. International Institute for Environment and Development (IIED), London.

99. Hodgson D. (2000). - Taking stock: state control, ethnic identity and pastoralist development in Tanganyika, 1948-1958. J. Afr. Hist., 41 (1), 55-78. doi:10.1017S0021853799007574.

100. Goldman M., Davis A. \& Little J. (2016). - Controlling the land they call their own: access and women's empowerment in northern Tanzania. J. Peasant Stud. E-pub.: 17 June. doi:10.1080/03066150.2015.1130701. 